\title{
A review on recent trends of antiviral nanoparticles and airborne filters: special insight on COVID-19 virus
}

\author{
Ali A. Jazie ${ }^{1}$ (D) Amar J. Albaaji ${ }^{2}$ (i) $\cdot$ Suhad A. Abed ${ }^{3}$ \\ Received: 3 September 2020 / Accepted: 1 June 2021 / Published online: 17 June 2021 \\ (C) The Author(s), under exclusive licence to Springer Nature B.V. 2021
}

\begin{abstract}
Novel corona virus (COVID-19) pandemic in the last 4 months stimulates the international scientific community to search for vaccine of antiviral agents suitable for in activating the virus inside and outside the human body. More than 4 million people globally are infected by the virus and about 300,000 dead cases until this moment. The ventilation and airborne filters are also investigated aiming to develop an efficient antiviral filtration technology. Human secretion of the infected person as nasal or saliva droplets goes as airborne and distributes the virus everywhere around the person. N95 and N98 filters are the must use filters for capturing particles of sizes around $300 \mathrm{~nm}$. The average size of the novel corona virus (COVID-19) is $100 \mathrm{~nm}$ and there is no standard or special filter suitable for this virus. The nanoparticle-coated airborne filter is a suitable technique in this regard. While the efficiency of this type of filters still needs to be enhanced, new developed nanofiber filters are proposed. Most recently, the charged nanofiber filters of sizes below $100 \mathrm{~nm}$ are developed and provide an efficient viral filtration and inactivation. The efficiency of filter must be kept at accepted level without increasing the pressure drop. The present review outlines the most efficient antiviral nanoparticles including the recent functional nanoparticles. The filtration theory, filtration modeling, filter testing, and different types of filter with special concentration on the charged nanofiber filter were discussed. The charged nanofiber filter able to capture novel corona virus (COVID-19) with 94\% efficiency and a pressure drop less than $20 \mathrm{MPa}$.
\end{abstract}

Keywords COVID-19 $\cdot$ Nano-aerosols $\cdot$ Air filtration $\cdot$ Nanoparticles $\cdot$ Nanoparticle-coated air filter $\cdot$ Charged fibers

\section{Introduction}

The demand for the ventilator, respirator, facemask, and body protection has been surging dramatically during the COVID-19 pandemic. To the date of writing this paper, the number of infections is soared exponentially, reaching to more than 3.4 million patients around the world, and around $7 \%$ of them died. Novel coronavirus belongs to the coronavirus family which includes MERS and SARS. Under

Ali A. Jazie

Ali.Jazie@qu.edu.iq

Amar J. Albaaji

amar.jabar@qu.edu.iq

1 Chemical Engineering Department, Engineering College, University of Al-Qadisiyah, Al-Diwaniyah, Iraq

2 Materials Engineering Department, Engineering College, University of Al-Qadisiyah, Al-Diwaniyah, Iraq

3 Department of Biology, College of Education, University of Al-Qadisiyah, Al-Diwaniyah, Iraq scanning electron microscope, the coronavirus seems like crown having a size averaged between 60 and $140 \mathrm{~nm}$. This profile has led to suggest the name for the virus (Zhu et al. 2020). Its height is $10 \mathrm{~nm}$, which is less than the height of SARS and MERS for the values of $15 \mathrm{~nm}$ and $18.5 \mathrm{~nm}$, respectively (Ather et al. 2020) (Konda et al. 2020). The spike protein nature with larger number of spikes makes the COVID-19 anchor and attacks the cells easily. The spikes help the virus to attach to droplets that come out of patients during influenza season (Huo et al. 2020) (R. Kumar et al. 2019). Accordingly, the spread aerosolize may transfer the virus to a long distances taking the advantage of small size for the virus (Zhu et al. 2020). The atmospheric aerosols can be divided relying on the size into less and greater than $100 \mathrm{~nm}$. The National Institute for Occupational Safety and Health (NIOSH) advises to use N95 and N99 filters to capture 300-nm aerosol sizes with efficiencies of 95 and $99 \%$, respectively, but there is no recommendation in case of aerosol size of less than $300 \mathrm{~nm}$ (Ge et al 2020). The National Institute for Occupational Safety and Health 
(NIOSH) limited the use of N95 and N99 to capture 300-nm aerosol sizes with efficiencies of 95 and $99 \%$, respectively, but there is no standard for less than $300 \mathrm{~nm}$. The common nonwoven microfiber filters can capture aerosols of sizes no less than $300 \mathrm{~nm}$. The aerosols may be in different shapes and sizes depending on the source (Bau et al. 2020). The atmospheric aerosols are divided depending on the size into nano-aerosols of $<100 \mathrm{~nm}$ and larger $(>100 \mathrm{~nm})$. The filtration efficiency is usually done based on the concentration of indoor and outdoor aerosols (Jeong et al. 2020). Very little number of studies has been done in order to fabricate air filters with the ability to work in continuous conditions of airflow and having a coating of antiviral activity (Liu et al. 2020) (Hirschmann et al. 2020). Charged nanofiber filter showed interesting filtration properties and the development studies on this type of antiviral filter by adding decorated graphene with nanoparticles may be the suitable target in the next step in fighting against novel corona virus (COVID-19). Many types of filters with nano-coating have been used for inactivating the viruses. In the current review, we are going to focus on recent antiviral nanoparticles used for coating on the surfaces of filters, method of preparation of nanoparticles, types of filters, woven, nonwoven, nanofiber, nanofiber electret filter, theory and modeling of filtration, testing of filter, and the mechanism of antivirus activities.

\section{Aerosols}

One of the most harmful pollutants for the air is the aerosol, especially the particulate matter of nanosize. The inhalation of PM causes a disorder in respiratory system, leading to difficulty in breathing (Matava et al. 2020). Nano-aerosols of size less than $100 \mathrm{~nm}$, which are contaminating the lungs, can easily penetrate into the bloodstream near the lungs. Reaching contaminates the brain by blood circulation system which causes many damaging effects in human body (Thamboo et al. 2020). It has been reported that the road emissions of aerosols are around of 200 million per cubic meter (Leung and Chau 2019). The classical microfiber filters are inactive for capturing all these types of aerosols; here, we will present the progress in nanofibers to tackle this issue.

\section{Viruses}

Many diseases are caused by very small nonliving particles, which have an infectious pathogenic effect and able to damage organs, tissues, and cells of the mammals and humans and even led to death (UCSF 2020) (Gerba and Betancourt 2017). This leads to an increase in annual human death to reach 2 million around the world (Colpitts et al. 2016). Vaccines are the most useful way for inactivation the viruses, but still, there are few of vaccines that have been explored. In 12th of March, the World Health Organization declared that the novel corona virus is a pandemic virus due to the speed of the virus spreading around the world. It is believed that the virus started from the animals in the city of Wuhan, China, in December 2019 and the infections continue to spread inside and outside China until reaching 3.4 million cases and the deaths of more than 240,000 in the globe until this moment (Huang et al. 2020). The evidences from Wuhan City proved that the novel coronavirus can spread from animal to human and from human to human in similar behavior with the SARS and MAERS which were declared for in 2003 and 2012, respectively (WHO 2019). It is believed that the infected person by novel corona virus can spread the infection to the other persons through the droplets by coughing and sneezing (Leung and Sun 2020). The size of droplets may be less or more than $50 \mathrm{~nm}$ in size (Cook 2020). In addition, the virus may be aerosolized during the vomiting and speech (Asadi et al. 2020). Consequently, the spread of the novel corona virus around the globe in this speedily manner may be explained depending on the above statements. Due to this pandemic, the need for efficient filtration increased strongly. TEM photos for novel coronal virus showed that the size of the virus around $100 \mathrm{~nm}$ and the conventional filtration technology cannot protect from this virus (Leung and Sun 2020). Figure 1 shows the
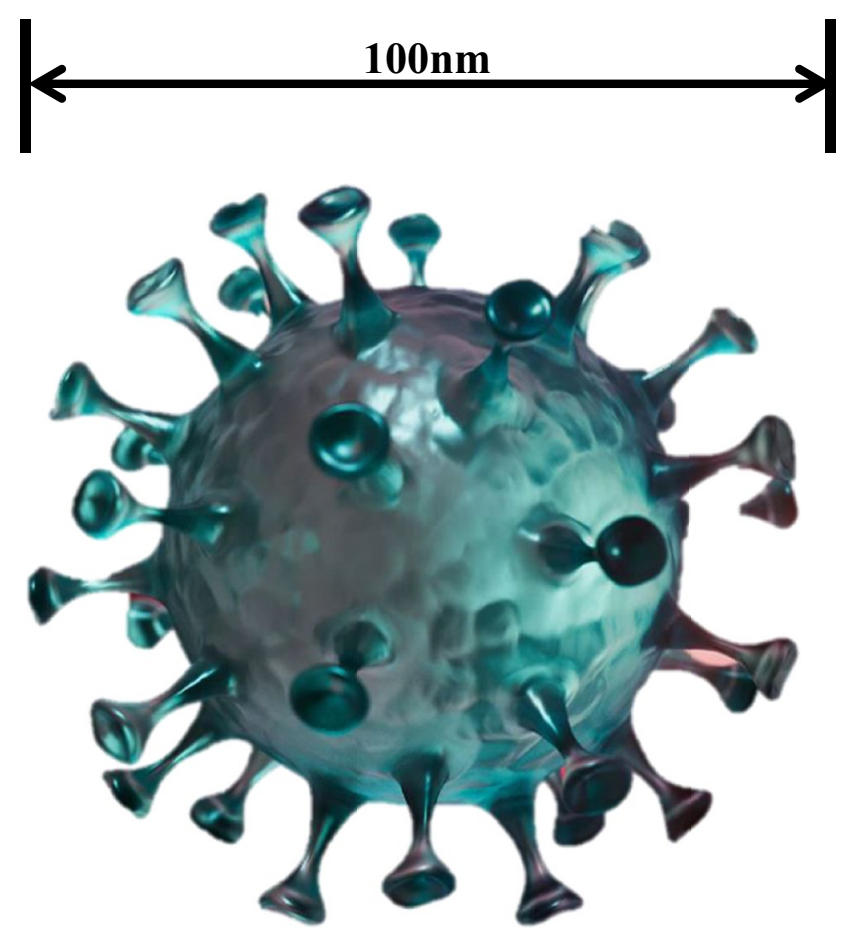

Fig. 1 Sketch showing the average size of the novel corona virus (COVID-19) 
average size of the virus. The new efficient filtration technology for viruses will be outlined in this work.

\section{Nanoparticles as antiviral agents}

\section{Nanoparticles of silver}

The physicochemical and biological properties of Ag nanoparticles (NPs) have attracted the attention of researchers to employ it in different applications such as drug delivery and for products to heal the burns and wounds (Nakamura et al. 2019) (Kulathunga et al. 2020). However, using Ag NPs for viruses inactivation is still in the beginning (Augustine and Hasan 2020) (Choudhary et al. 2020). The Ag NPs have been investigated as antivirus agent for inactivating some viruses lick HIV, H1N1, parainfluenza, HSV1, and hepatitis B (Kim et al. 2020). Moreover, a green preparation method for obtaining lick spherical particles of Ag NPs has been tested by the researcher to be as an antiviral for the virus of H1N1, which inhibits H1N1 (Dung et al. 2019) (Moradi et al. 2017). Moreover, Ag NPs resist the ROS production and though inactivate the neuraminidase. The hydrogel of Ag NPs prepared by tannic acid shows an efficiency for inactivating HSV1 and HSV2 viruses as well (Szymańska et al. 2018) (Gherasim et al. 2020).

\section{Nanoparticles of gold}

Gold nanoparticles have been used in the nanomedical and diagnostic applications owing to their superior mechanical, optical, and electrical properties (Ambekar et al. 2020) (Sánchez-López et al. 2020). DNA and proteins were detected by Au NPs, and different methodologies are employed for preparing Au NPs (Rathore et al., 2020) (Chen and Liang 2020) (Slepička et al. 2020). Rosi and co-workers were first to prepare Au NPs for the biological and medicinal applications (Rosi and Mirkin 2005). In order to inhibit the HSV1 virus, the Au NPs were used, which were stabilized by gallic acid using ultrasonic technique and characterized using the plaque reduction neutralization test (Kim et al. 2020). Another study utilizes hyaluronic modified Au NPs for inactivation of hepatitis C virus (M. Y. Lee et al. 2012). Moreover, the gold nanoparticles have been utilized effectively in antiviral used for HIV, HSV1, and influenza (Milovanovic et al. 2017) (Ringe et al. 2019) (Senapathi et al. 2020). The activity of Au NPs is affected by the size of the particles concerning the size of the virus. The efficiency of nanoparticles will be higher as long as their size is larger than the size of the virus (Vonnemann et al. 2014).

\section{Nanoparticles of graphene oxide}

Geim and Novoselov have discovered graphene in 2004. Graphene is a material composed of carbon and having a hexagonal structure in two dimensions with an exceptional thick of single atom. Unique thermal, electrical, and mechanical properties for graphene and derived materials have drawn the attention for researchers to utilize it in different applications (Ghosal and Sarkar 2018) (Dave et al. 2016). Many researches have been done in biomedical field relying graphene oxide as antiviral (X. Wang et al. 2010). Graphene oxide was functionalized by curcumin for inactivating the RSV virus through the work of Huang et al. (Yang et al. 2017). The authors suggested three possible for antiviral mechanism: (1) direct inactivation, (2) prevent the host cell form virus attaching, and (3) disturb the replication of virus. Moreover, a nanomaterial of multifunctional modified graphene oxide was fabricated as an antiviral agent for HSV1 virus (Sametband et al. 2014). Quantum dots-graphene oxide have used as antiviral agent by a researches for inactivating the HIV virus (Iannazzo et al. 2018) (Yousaf et al. 2017).

\section{Nanoparticles of mesoporous silicon}

The antiviral drugs are failing in some situation, due to the problem in releasing the drug, and nanoparticles of mesoporous silicon were proposed as carrier for solving this limitation (De Clercq 2010) (Pan et al. 2014) (Ye et al. 2016) (Haimov et al. 2018). This type of antiviral agent was examined for inactivating the HSV1, HSV2, HIV, and VEEV viruses (Compton et al. 2017) (LaBauve et al. 2018). The advantage of mesoporous nanoparticles is that having low cytotoxicity and high stability compared to Au and Ag NPs (De Souza E Silva et al. 2016).

\section{Nanoparticles of dendrimers and polymers}

Nanoparticles of polymers have been used as an antiviral agents for their flexibility in molecular design (Dzhardimalieva et al. 2020) (K. J. Lee et al. 1999). A wide range of polymers reported as an efficient antiviral agents and one of these polymers is the organotin, which show excellent activity (Rzaev and Sadykh-Zade 1973) (Carraher and Roner 2014). Polymers may show antiviral activity even if the virus is not entering the cell (Y. Wang et al. 2011) (Chun et al. 2018). Many viruses lick HCV and influenza A were inactivated efficiently using polymer NPs (Lancelot et al. 2017) (Jyothi et al. 2015). Moreover, sexual transmission of HCV was prevented using dendrimers (Sepúlveda-Crespo et al. 2015). 


\section{Nanoparticles of green metals}

Nanoparticles were also prepared using green biotechnology methods from green sources lick algae, fungi, bacteria, plants, and human cells used as antiviral agents (Zeedan et al. 2020) (Mohamed et al. 2020). The nanoparticles prepared by green sources are used as stabilizing and capping agents (Chandra et al. 2020) (Das and Karankar 2019). The most used nanoparticles in biomedical application, which are gold, and silver nanoparticles are prepared by the green route (Kuppusamy et al. 2015) (Salem and Fouda 2020). Using various plant extracts, mono-, di-, and tri-metallic nanoparticles were prepared but still have some limitations in the state of aggregation, stability, and crystal growth (Guimarães et al. 2020) (Gomathi et al. 2020).

\section{Functionalized nanoparticles}

Nanozymes were prepared as an artificial nanoparticles for treating $\mathrm{HCV}$ virus using the mechanism of RNA mediation by RISC (X. Zhang et al. 2014) (Z. Wang et al. 2012). It is tested in muse and found there is no any interference or toxicity of nanozymes detected in the muse cells while the antiviral activity against HCV virus was found excellent. Moreover, nanozyme preparation method is very simple and can be done in two steps. First, RNase is added to the NPs at $\mathrm{pH}$ of 9.6 using a buffer solution of carbonate. Second is the modification of NPs by antiviral agent of HCV (Pollock et al. 2010). Rare earth metal NPs have been used as antiviral agent for Zika virus (Ortega-Berlanga et al. 2020), while alumina modified with $\mathrm{CuO}$ NPs have been utilized as functional antiviral agent for HSV1 (Mazurkow et al. 2020) (Tavakoli and Hashemzadeh 2020). It has been suggested in Nabila et al. (2019) and Derbalah et al. (2019) that the NiO can be used for inactivating CMV. An antiviral for influenza has been prepared relying on $\mathrm{ZrO} 2, \mathrm{ZnO}$, and $\mathrm{TiO} 2$
(Mazurkova et al. 2010). Recently, a recognized rising in the research for functionalized NPs as antiviral agents is seen.

\section{The mechanism of antivirus activities}

The antiviral activity of the nanoparticle agent acts on the virus membrane directly and decomposes it or by binding to the corona protein of the virus. Ag NPs activity on many viruses is explained in different studies and interpreted by the binding of agent with the glycoprotein of the virus membrane in the differentiation cluster 4 (CD4) in case of HIV-1 virus and HBV virus (Siadati et al. 2020). Moreover, the agents react with enzymes of the virus by binding to the imidazole, carboxyl, amino, phosphate, and sulfide groups (Borkow and Gabbay 2004). It has been reported recently that the mechanism of Ag NPs antiviral activity can be explained by the generation of reactive oxygen species (ROS) which create a silver ions and reduce stress (Kora and Sashidhar 2018). Consequently, it is suitable materials for healthcare and filtration uses against virus infections (Clement 2012). The mechanism of inactivation the virus by $\mathrm{Ag}$ NPs is shown in Fig. 2 (Ishihara et al. 2015).

\section{Nanoparticles preparation}

\section{Sol-gel technique}

Sol-gel is a simple, low-temperature, and economic technique, which is suitable for nanoparticles synthesis. The procedure consists from the following subsequent steps: (1) production of metal hydroxide through the hydrolysis of metal, (2) 3D gel creation through the fast condensation step, (3) aerogel and xerogel production through the fast drying of gel (Owens et al. 2016). The sol-gel method is used to produce nanoparticles of homogeneous
Fig. 2 The mechanism of antiviral activity of the $\mathrm{Ag}$

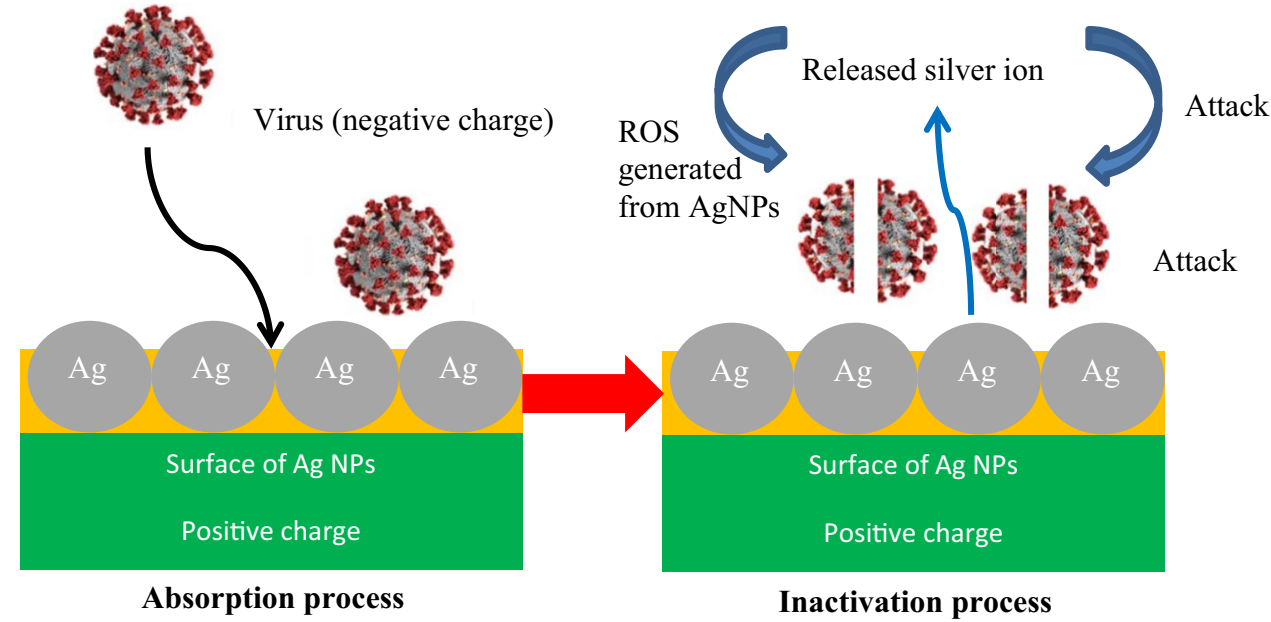


structure and high purity (Ahmed et al. 2020) (Pierre 2020). Figure 3 shows the steps of the sol-gel methods.

\section{Polyol technique}

Polyol technique depends on the polyol reaction using ethylene glycol or any other chemicals having polyol functional group. The polyol agents have many roles such as solvent, reducing, complexion with stabilizing agent, and medium for the preparation process (Ferdous and Nemmar 2020) (Iravani and Varma 2020). To obtain nanoparticles by this procedure, cheap metal salts are added to aqueous solution including polyol agent and specific amount of sulfuric acid. The mixture is then heated to the boiling point temperature until the reaction completion. After that, the solution is kept to cool down to room temperature, and the nanoparticles are separated by centrifugation; the nanoparticles are then washed thoroughly by ethanol and dried (Zeroual et al. 2020). Figure 4 displays a schematic diagram showing the steps of the polyol technique for Ag NPs production.

\section{Micro-emulsion}

Micro-emulsion is an inorganic technique to produce nanoparticles, which depends on a system composed of surfactant, nonpolar, and polar contents. Micro-emulsion solution is stable, homogeneous, and isotropic system (Malik et al. 2012) (H. Kumar et al. 2020). The reactant materials are mixed with the micro-emulsion material by the water droplet collision. Then, steps of precipitation, nucleation, and coagulation occur leading to produce of nanoparticles enclosed by water (Rane et al. 2018).

\section{Hydrothermal synthesis}

It is one of the favorable green methods which is used for the production of inorganic nanoparticles (Darr and Poliakoff 1999) (Beyer et al. 2020). Hydrothermal technique gained attention as it is done in the liquid phase (water) (Bartkowiak et al. 2018) (Jaggessar and Yarlagadda 2020). The process is done by preheating the water under a high-pressure stirred reactor; the metal salts are added continually, leading to the production of metal oxide nanoparticles (Darr and Poliakoff 1999).
Fig. 3 The steps of the sol-gel method
Fig. 4 Schematic diagram of polyol steps process for Ag NPs production

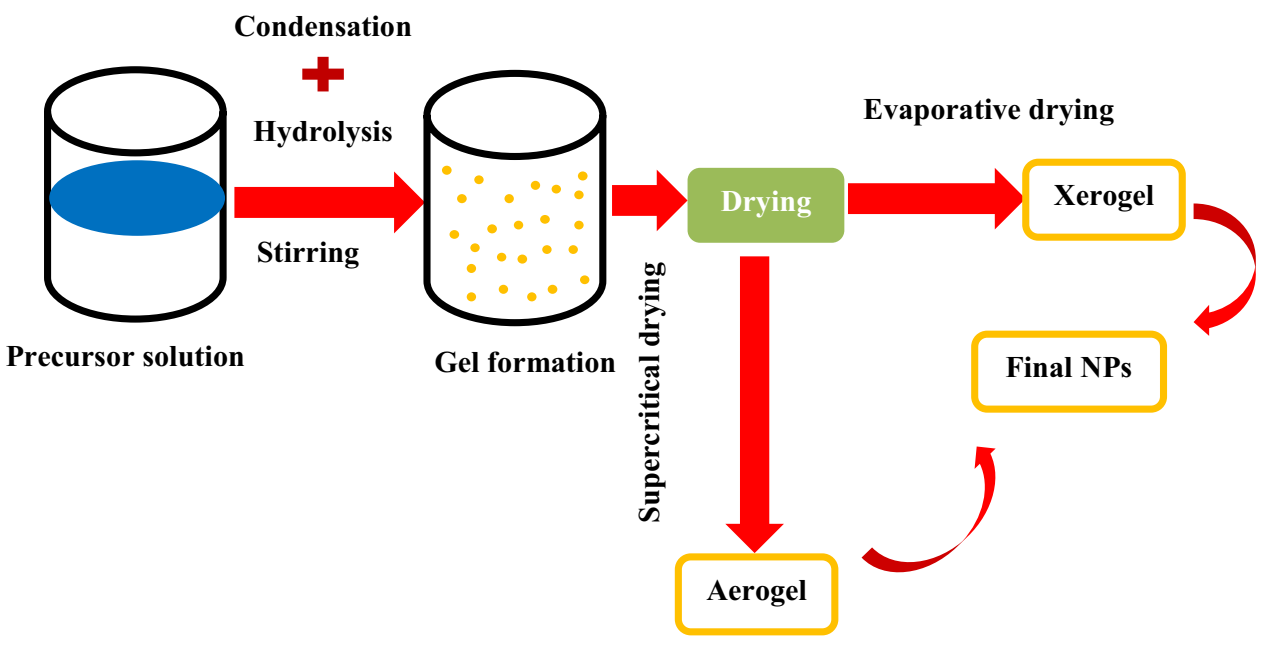

\section{Dissolved precursor solution}

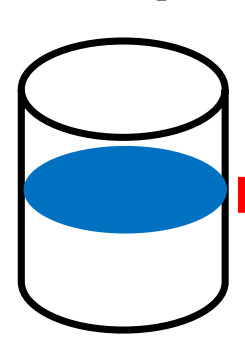

Heating at room temperature

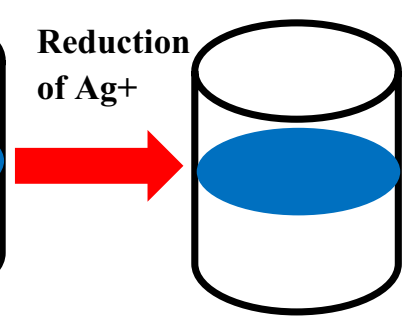

Nucleation

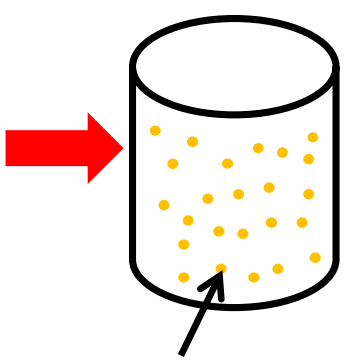

Ag+ Nuclei

\section{Growth}

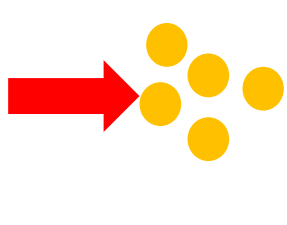

Ag NPs 


\section{Green synthesis routes of metal nanoparticles}

Recently, the nanoparticles are produced using plant extracts and microbes (viruses, bacteria, and fungi); the procedure is ecofriendly, safe, and efficient (Gowramma et al. 2015) (Shah et al. 2015). However, many advantages are achieved by this procedure concerning microbial method, and it is easy to control the size and morphology of the nanoparticles in the later through temperature and pH of microbe cell (Iravani 2011) (Patil et al. 2011). Figure 5 shows the green methods used for metallic NPs production.

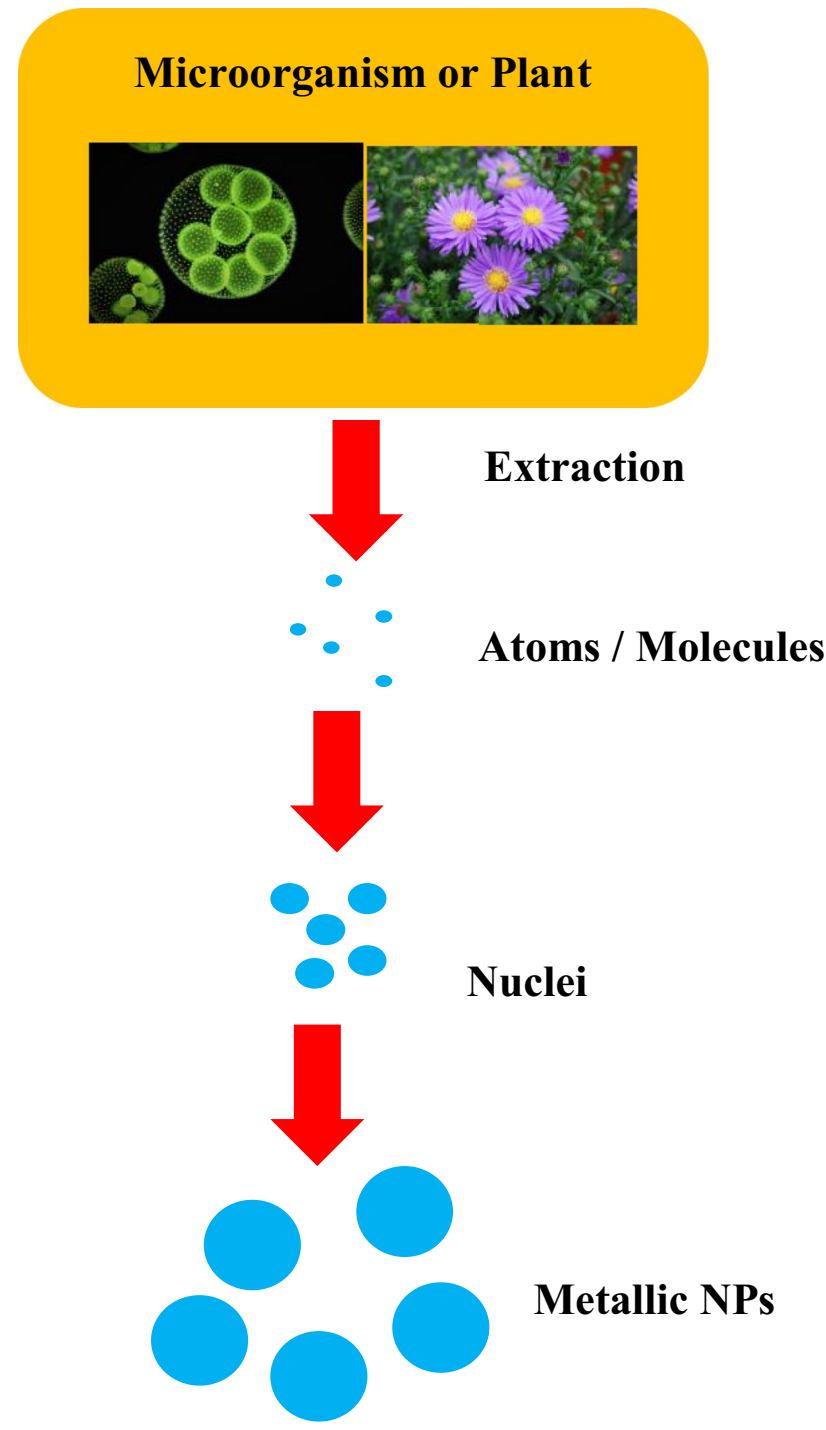

Fig. 5 The green methods used for metallic NPs production

\section{Air filters}

Nowadays, there is an urgent need for filters with high quality, due to the fast development in the viruses. The nanosized virus (COVID-19) is very aggressive in attacking the human body, due to the nature of spikes on its surface and the tiny size. Therefore, the specifications are required for the novel filter to be able to filtrate aerosols of size less than the size of $100 \mathrm{~nm}$ and also able to inactivate the virus (Tian et al. 2018). Many types of filters are used for filtration; the different sizes of aerosols lick woven, nonwoven, nanoparticle-coated, nanofiber, and nanofiber electret filter (Feng and Cao 2019). The subsequence sections will discuss in details the most recent technologies, which are used for developing an efficient antiviral filters. Figure 6, the schematic diagram, shows the antiviral efficiency of filter.

\section{Modeling of antiviral air filter activity}

The following section discusses the theoretical base for the filter efficiency based on the number of fiber layers.

\section{Filtration model for single fiber}

The total efficiency of the filter (E) for single fiber type depends on the parameters of air velocity, fiber properties, and particle size. Davies (Davies 1983) presents the equation for the total efficiency for single fiber filter as follows (Eq. 1).

$E=1-e^{-E_{S} S}$

where $E, S$, and $E_{\mathrm{s}}$ are the total efficiency, dimensionless projected area of fiber (depend on the fiber diameter, packing density, and thickness of the filter), and fractional fiber efficiency, subsequently (Sambaer et al. 2012). The mechanism of filtration occurred according to the above equation consists of three steps (impaction, interception, and diffusion).

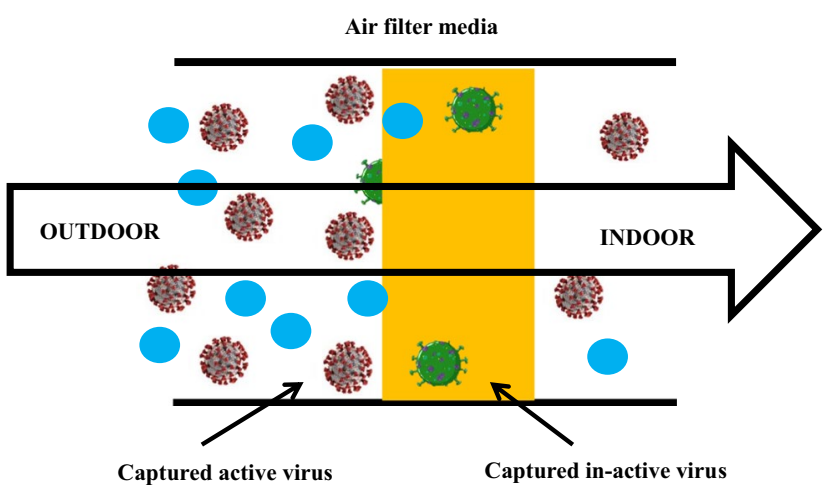

Fig. 6 Schematic diagram of the filter antiviral efficiency 
When the inertia of particles is high, impaction occurs and this step is neglected for the most filter types, while the interception is dominated in this case for particles size more than $1 \mu \mathrm{m}$ (Brown and Wake 1991) (Graham et al. 2002). The smaller particle of less than $0.1 \mu \mathrm{m}$ is subjected to the diffusion process due to the Brownian motion effect (Davies 1983).

\section{Filtration model for multi-fiber}

For the fibers of diameters ranging from 0.65 to $6.5 \mu \mathrm{m}$, the total efficiency equation (Eq. 1) can be applied after changing the projection area. The projection area for multi-fiber filter can be calculated according to Eq. 2 as follows:

$E_{S} S=\sum E_{s i} S_{i}$

where $E_{\mathrm{si}}$ is the single fiber efficiency.

\section{Filter types}

\section{Nanoparticle-coated air filters}

Antimicrobial agents of different nanoparticles have been investigated in the continuous flow mode as coating on the surface of filters (Huang et al. 2020). A researcher developed iodine-releasing filter as antiviral coating against MS2 virus aerosols (J. H. Lee et al. 2009). Moreover, $\mathrm{TiO}_{2}, \mathrm{Ag}-\mathrm{Cu}$, iodine-activated resin, and Enviz $\mathrm{O}_{3}$-Shield agents developed by another researcher as antiviral coatings on filters for inactivating MS2 virus (Rengasamy et al. 2010). Cellulosic filter with dialdehyde group coated with different nanoparticles agent shows a good efficiency against MS2 virus also (Rengasamy et al. 2010). $\mathrm{SiO}_{2}$-Ag NPs have been proposed as efficient antiviral agent for inactivating MS2 virus by dry coating on a commercial filter (D. H. Park et al. 2019).

CNTs and Ag NPs have been proved as a good antiviral agent for MS2 virus by coating on the surface of a fiber glass filter (K. T. Park and Hwang 2014). Moreover, magnetic particles are also investigated as antiviral agent. Magnetic silica decorated with Ag NPs showed an excellent antiviral activity if it is coated on the fiber filter (H. Z. Zhang et al. 2016). Magnetic silica particles were functionalized with aminopropyl as a dispersive agent in the liquid phase, and then were coated by Ag NPs to use as filter for antiviral activity (H. H. Park et al. 2013).

\section{Nonwoven}

Nonwoven filters are efficient antiviral filters which are adopted for industrial and personal usages (Stetzenbach et al. 2004). The mechanism of this filter depends on diffusion, which enables capture aerosols less than $100 \mathrm{~nm}$, while the interception is the mechanism for aerosols in the range of $100 \mathrm{~nm}$ to $1 \mu \mathrm{m}$.

\section{Nanofiber}

Filters were fabricated from nanofibers of diameter less than $1 \mu \mathrm{m}$ and a high surface area was found to be suitable for facemask, due to the amount of nanofiber needed very small (less than $1 \mathrm{~g} / \mathrm{m}^{2}$ ) (Ahn et al. 2006). The pressure drop is high in the case of using nanofiber filters compared to microfiber filters according to Davis' equation (Davies 1953). The pressure drop may increase by 100 times that for the microfiber filter of the same weight.

\section{Multilayer and multi-modules stack-up}

As an effort for solving the problem of higher pressure in the nanofiber filter, multi-thin layer of nanofiber has been used on a macropore substrate (Leung and Sun 2020). The same filtration efficiency is obtained using multilayer filter compared to the single-layer filter with reducing the pressure drop (Leung et al. 2010).

\section{Electret nanofiber filter}

In the previous sections, we discuss the nanofiber filter of 200- to 600-nm fiber diameter that can be effective in capturing aerosols of size less than $100 \mathrm{~nm}$ (the diameter of COVID-19 virus), and it was found that this type of filter is suffering from the high pressure drop. A new technology for enhancing the efficiency of filtration without increasing the pressure drop is the charging of nanofibers with electrostatic charges. The challenging issue in this regard is the stability of nanofiber charges (Thakur et al. 2013). Recently, corona discharge method has been used for charging polyvinylidene fluoride (PVDF) and has been showed a stability for 3 months (Leung and Sun 2020) (L. Y. Wang et al. 2020). The efficiency of the charged nanofiber filter was found much efficient than the microfiber filter of $15-\mu \mathrm{m}$ average diameter (Sun and Leung 2019).

Multilayer PVDF electret filter showed a promising filtration efficiency and reduction in pressure drop compared to the single-layer one (Sun and Leung 2019). The filter efficiency and pressure drop are continuously changed with increasing the aerosol loading (Leung and Sun 2020) (Sun and Leung 2020). This type of filter is considered more efficient from the viewpoint of energy consumption, health activity, and cost. Initially, the filtration efficiency of charged filter reduces with increasing the loading of aerosols and then increases due to the phenomena of electrostatic shielding by aerosol deposition and mechanical capture which form an effective surface media for the filter (Röhrig and Diebels 2019). 
The mechanism of filtration for charged filters is summarized as follows: (i) initially, the aerosol capture done using the coulomb force of charged and induction of uncharged aerosols, (ii) the captured aerosols in the initial step then act as a trap for the next aerosols, which form a dendritic structure with continuing the filtration process. A cake of connected aerosols will cover the surface of the charged filter that reduces the electrostatic effect. Nevertheless, the mechanical collection of aerosols increases until the equilibrium is done between the mechanical capture efficiency and the electrostatic efficiency. A similar increasing behavior in the pressure drop is reported for the electret filter as compared to the normal filter (Schutz and Church 2011). Once the filter is clogged, it is working as surface filter. Researchers reported that some electret filter might have lower clogging rate due to the uniform distribution of deposited aerosols. Scanning electron microscopy (SEM) studies can support the above results (Schutz and Church 2011). The thickness of electret filter is high even for that of single-layer nanofiber filter and the deposition of the aerosols occurs at the face more than the backside of the filter (Leung et al. 2009).

The filtration efficiency can be controlled by stacking the multiple layers of nanofiber from thicker to thinner one (Sun and Leung 2020). Multi-thin layer nanofiber filter of the same weight may take a long time to be clogged by the aerosols as compared to the single-layer nanofiber filter due to the small thickness and porosity. This phenomena lead to uniform distribution of captured aerosols as seen in the images of SEM. From the above discussions, it is concluded that the charged multilayer nanofiber PVDF filter is a new emerging technology and can be modified in order to increase the filtration efficiency, decreasing the pressure drop. Moreover, coating charged nanofiber PVDF filter with antiviral nanoparticle agents like graphene may open up a new prospect for developing antiviral filters to fight the novel corona virus (COVID-19).

\section{Testing of antiviral filters}

The antiviral activity of the filters is measured using the logarithmic reduction value (LRV) for the titer of the virus, where LRV value provides evidence about the elimination of the virus and used as a safety factor. LRV values depend on less than $0.01 \%$ part of the virus collected in the filtrate and the rest of the virus are still in the filter and not detectable. The complete information on the virus holding in the filter cannot be obtained in this method. Therefore, techniques of artificial nanoparticle from gold or nanoparticle of fluorescent label have been used for better understanding the nanofiltration process (Yamaguchi et al. 2007). These techniques provide a precious method for detecting the virus in the filter and find the relation between the pore size distribution and the virus detection using electron or fluorescence microscopy (Kosiol et al. 2017). Laser scanning microscopy (LSM) is another method used for detecting the virus in the filter (Bakhshayeshi et al. 2011). The above methods are reproducible and fast method for visualizing the particles using different dyes and provide understanding for the viral detection throughout the fouling and depressurizing actions (Jackson et al. 2014). MS2, PP7, and $\Phi X 174$ bacteriophages are the most useful substitute used for investigating the filter antiviral activity as it is of size similar to that of the parvovirus (Slocum et al. 2013).

Direct imaging is a good method for understanding the mechanism of virus retention in the filter but it is not providing a model reflecting the real phenomena in the membrane. The capsid of the virus surface usually interacted with the membrane of the antiviral agent and each virus have special interaction (Kosiol et al. 2019). Moreover, the filtrations conditions and filter material are also affecting the retention of the virus in the filter. From the above, we can conclude that the parvovirus model cannot be used every time. A few works provided an image for the parvovirus retention mechanism in the filter using immune detection and SEM for PPV and B19V (Adan-Kubo et al. 2019) (Hongo-Hirasaki et al. 2011). Moreover, TEM technique is also used for detecting the viral particles in the filter membrane. In a recent study, a method has been developed for detecting quantitatively virus retention phenomena in the filter to provide a good understand for the nanofiltration process (Leisi et al. 2020).

The most important test method for the filter is done by aerosolizing the MS2 virus using an atomizer for obtaining a uniform distribution of the virus on the surface of the filter by forced convection flow. At that point, the virus collected on the surface of the filter is removed to a liquid media containing E. coli $\mathrm{C} 3000$ by vibration method (shaking, sonication, or vortex). Afterward, plaque counting method is used for evaluation of the nanoparticle activity (Tellier 2006). Air filters used for indoor air cleaning system are important for healthcare places so that the air media test is more a useful one (Siegel et al. 2007). A recent study reported novel method for testing the antiviral activity of airborne filter. The testing method was done in a liquid media containing dispersion of $\mathrm{H} 1 \mathrm{~N} 1$ virus and then the plaque test is used for the liquid media. Also, a correlation equation is used for converting the plaque test data to air media data (D. H. Park et al. 2020). Finally, vulnerability is the best method for explaining the antiviral efficiency lick $\mathrm{Ag}$ and $\mathrm{Cu}$ NPs coating density on the filter (Yoon et al. 2007).

\section{Conclusion}

The concluded points from the present review are summarized as follows: 
1. Nanoparticles as antiviral agents are widely investigated in addition to the field of biomedicine and biosensors.

2. Ag NPs, Au NPs, graphene oxide NPs, dendrimers NPs, and Si NPs are the most functional antiviral materials used in vivo and in vitro which form the future materials for fighting the viruses.

3. The biocompatibility of the functional nanoparticles is an important issue that has to be spotlighted and improved.

4. The effective techniques chosen for the preparation of functional nanoparticles can solve the limitation related to the biocompatibility issue.

5. The development of a suitable functional nanoparticle for a specified virus is a challenging job.

6. The conservation of the antiviral activity for the functional nanoparticles during the binding state with virus is another important job that has to be investigated.

7. The mechanism of inactivating the virus by the functional nanoparticles is still not well known and a new work in this field has to be done.

8. The in vivo delivery of the functional nanoparticles is another field that should be studied more.

9. The nanostructure of the functional nanoparticles should be developed carefully to consider the mutation of the virus also.

10. Stability and toxicity of the functional nanoparticles is a wide field for the researches on the developments of functional nanoparticles.

11. Nanoparticles preparation techniques are discussed in this review, and from these methods, it was found that the green one is a promising, and the future studies using this method are an emerging issue.

12. Phytometabolites are the plant extract useful for synthesis of nanoparticles in the green route.

13. Nanoparticles from biological sources are free from toxic materials.

14. Green methods have advantages of bio-functionality along with the physical and chemical functionalities.

15. The antiviral activity test of the airborne filter is investigated in the continuous airflow by eluting the virus into a liquid media.

16. Electret PVDF nanofiber filter has been used extensively and showed a stability of the charge using the corona discharge method.

17. Single- and multilayer electret filters have been tested for the antiviral activity.

18. Simulated sodium aerosols were used for testing the filter activity against novel corona virus (COVID-19).

19. Nanofiber filter of small fiber size has higher mechanical ability to capture the aerosols by interception and diffusion due to the increase of the surface area of the nanofiber.
20. Diffusion is the main mechanism for capturing aerosols less than $100 \mathrm{~nm}$ (size of the COVID-19 virus) in the nanofiber filter.

21. Charging the nanofiber filter with electrostatic charge enhances the capture of nano-aerosols.

22. Using multilayer of nanofibers in the filter may reduce the pressure drop by adding a macropore.

23. Charging small diameter fiber filter may increase the interference of electrical charge with other fibers in the same layer.

24. Increasing the basis weight for large diameter fiber increases the electrostatic capture efficiency and did not increase the pressure drop.

25. The pressure drop proportioned inversely with the fiber diameter.

26. For increasing the efficiency of the charged multilayer nanofiber filter without increasing the pressure drop, the suitable strategy used in this regard is to decrease the basis weight for each layer.

27. The target of the recent studies for developing the electret nanofiber filter is the capturing of aerosols less than $100 \mathrm{~nm}$ (size of COVID-19 virus) with efficiency of $90 \%$ and a pressure drop no more than $30 \mathrm{~Pa}$.

28. Stacking multilayer of fine nanofiber using small basis weight reduces the pressure drop to the target of $30 \mathrm{~Pa}$.

29. Using high basis weight and large nanofiber diameter or vice versa for the charged multilayer nanofiber filter gave high efficiency of $90 \%$ in capturing simulated novel corona virus 100-nm sodium chloride aerosols.

30. Engineered charged nanofiber filter for obtaining a high filtration efficiency for capturing aerosols of corona viruses especially COVID-19 virus without increasing the pressure drop of more than $30 \mathrm{~Pa}$ is the recommended target for new researches in this field.

\section{Recommendation}

1. Graphene with single atom thickness is promising material to be used as antiviral for virus of nanosize; despite there are rare researches in this area, many parameters are need to be covered.

2. It has been reported that some materials such as Ag and Au can be used effectively as antiviral decoration graphene nanoparticles by these materials as agent against COVID 19 has not done yet.

3. CNTs have been used in filters fabrication, and testing these filters against crown viruses is still in the beginning.

4. Using special alignment for carbonaceous nanomaterials in filters may raise the efficiency of filtration against crown viruses. 
5. Charged nanofiber filter showed interesting filtration properties and the development studies on this type of antiviral filter by adding decorated graphene with nanoparticles may be the suitable target in the next step in fighting against novel corona virus (COVID-19).

Acknowledgements The authors appreciate the help provided by the Department of Chemical Engineering at the University of Al-Qadisiyah.

Data availability Data sharing is not applicable to this article as no datasets were generated or analyzed during the current study.

\section{Declarations}

Conflict of interests The authors declare competing interests.

\section{References}

Adan-Kubo J, Tsujikawa M, Takahashi K, Hongo-Hirasaki T, Sakai K (2019) Microscopic visualization of virus removal by dedicated filters used in biopharmaceutical processing: Impact of membrane structure and localization of captured virus particles. Biotechnol Prog 35(6):1-11. https://doi.org/10.1002/btpr.2875

Ahmed DS, Mohammed MKA, Mohammad MR (2020) Sol-gel synthesis of Ag-doped titania-coated carbon nanotubes and study their biomedical applications. Chem Pap 74(1):197-208. https:// doi.org/10.1007/s11696-019-00869-9

Ahn YC, Park SK, Kim GT, Hwang YJ, Lee CG, Shin HS, Lee JK (2006) Development of high efficiency nanofilters made of nanofibers. Curr Appl Phys 6(6 SPEC. ISS):1030-1035. https:// doi.org/10.1016/j.cap.2005.07.013

Ambekar RS, Choudhary M, Kandasubramanian B (2020) Recent advances in dendrimer-based nanoplatform for cancer treatment: a review. Eur Polymer J 126:109546. https://doi.org/10.1016/j. eurpolymj.2020.109546

Asadi S, ben Hnia NG, Barre RS, Wexler AS, Ristenpart WD, Bouvier NM (2020) Influenza a virus is transmissible via aerosolized fomites. Nat Commun 11(1):1-9

Ather A, Patel B, Ruparel NB, Diogenes A, Hargreaves KM (2020) Coronavirus disease 19 (COVID-19): Implications for clinical dental care. J Endod 46(5):584-595. https://doi.org/10.1016/j. joen.2020.03.008

Augustine R, Hasan A (2020) Emerging applications of biocompatible phytosynthesized metal/metal oxide nanoparticles in healthcare. J Drug Deliv Sci Technol 56:101516. https://doi.org/10.1016/j. jddst.2020.101516

Bakhshayeshi M, Jackson N, Kuriyel R, Mehta A, van Reis R, Zydney AL (2011) Use of confocal scanning laser microscopy to study virus retention during virus filtration. J Membr Sci 379(12):260-267. https://doi.org/10.1016/j.memsci.2011.05.069

Bartkowiak A, Suchanek K, Menaszek E, Szaraniec B, Lekki J, Perzanowski M, Marszałek M (2018) Biological effect of hydrothermally synthesized silica nanoparticles within crystalline hydroxyapatite coatings for titanium implants. Mater Sci Eng: C 92:88-95. https://doi.org/10.1016/j.msec.2018.06.043

Bau S, Rousset D, Payet R, Keller FX (2020) Characterizing particle emissions from a direct energy deposition additive manufacturing process and associated occupational exposure to airborne particles. J Occup Environ Hyg 17(2-3):59-72. https://doi.org/ 10.1080/15459624.2019.1696969

Beyer J, Mamakhel A, Søndergaard-Pedersen F, Jinlong Yu, Iversen BB (2020) Continuous flow hydrothermal synthesis of phase pure rutile $\mathrm{TiO} 2$ nanoparticles with a rod-like morphology. Nanoscale 12(4):2695-2702. https://doi.org/10.1039/c9nr09069j

Borkow G, Gabbay J (2004) Putting copper into action: Copperimpregnated products with potent biocidal activities. FASEB J 18(14):1728-1730. https://doi.org/10.1096/fj.04-2029fje

Brown RC, Wake C (1991) Air filtration by interception-theory and experiment. J Aerosol Sci 22(2):181-186

Carraher CE, Roner MR (2014) Organotin polymers as anticancer and antiviral agents. J Organomet Chem 751:67-82. https://doi.org/ 10.1016/j.jorganchem.2013.05.033

Chandra H, Kumari P, Bontempi E, Yadav S (2020) Medicinal plants: treasure trove for green synthesis of metallic nanoparticles and their biomedical applications. Biocatal Agric Biotechnol 24:101518. https://doi.org/10.1016/j.bcab.2020.101518

Chen Lu, Liang J (2020) An overview of functional nanoparticles as novel emerging antiviral therapeutic agents. Mater Sci Eng, C 112:110924. https://doi.org/10.1016/j.msec.2020.110924

Choudhary S, Kumar R, Dalal U, Tomar S, Reddy SN (2020) Green synthesis of nanometal impregnated biomass - antiviral potential. Mater Sci Eng C 112:110934. https://doi.org/10.1016/j. msec.2020.110934

Chun H, Yeom M, Kim HO, Lim JW, Na W, Park G, Park C et al (2018) Efficient antiviral co-delivery using polymersomes by controlling the surface density of cell-targeting groups for influenza a virus treatment. Polym Chem 9(16):2116-2123. https://doi.org/ $10.1039 / \mathrm{c} 8$ py00116b

Clement R (2012) Is it time for an evidence based uniform for doctors? BMJ (online) 345(7888):1-4. https://doi.org/10.1136/bmj.e8286

De Clercq E (2010) Highlights in the discovery of antiviral drugs: a personal retrospective. J Med Chem 53(4):1438-1450. https:// doi.org/10.1021/jm900932g

Colpitts CC, Verrier ER, Baumert TF (2016) Targeting viral entry for treatment of hepatitis B and C virus infections. ACS Infectious Diseases 1(9):420-427. https://doi.org/10.1021/acsinfecdis. $5 \mathrm{~b} 00039$

Compton JR, Mickey MJ, Xin Hu, Marugan JJ, Legler PM (2017) Mutation of Asn-475 in the Venezuelan equine encephalitis virus NsP2 cysteine protease leads to a self-inhibited state. Biochemistry 56(47):6221-6230. https://doi.org/10.1021/acs.biochem. $7 \mathrm{~b} 00746$

Cook TM (2020) Personal protective equipment during the COVID-19 pandemic - a narrative review. Anaesthesia. https://doi.org/10. 1111/anae. 15071

Darr JA, Poliakoff M (1999) New directions in inorganic and metalorganic coordination chemistry in supercritical fluids. Chem Rev 99(2):495-542

Das P, Karankar VS (2019) New avenues of controlling microbial infections through anti-microbial and anti-biofilm potentials of green mono-and multi-metallic nanoparticles: a review. J Microbiol Methods 167:105766. https://doi.org/10.1016/j.mimet.2019. 105766

Dave SH, Gong C, Robertson AW, Warner JH, Grossman JC (2016) Chemistry and structure of graphene oxide via direct imaging. ACS Nano 10(8):7515-7522. https://doi.org/10.1021/acsnano. 6b02391

Davies CN (1953) The separation of airborne dust and particles. Proceedings of the Institution of Mechanical Engineers, Part b: Management and Engineering Manufacture 1(1-12):185-213. https:// doi.org/10.1177/095440545300100113

Davies CN (1983) Filtration of Aerosols. J Aerosol Sci 14(2):147-161. https://doi.org/10.1016/0021-8502(83)90039-3 
Derbalah H, Soliman A, Elsharkawy MM (2019) A New Strategy to Control Cucumber Mosaic Virus Using Fabricated NiO-Nanostructures. J Biotechnol 306(September):134-141. https://doi. org/10.1016/j.jbiotec.2019.10.003

Dung TTN, Nam VN, Nhan TT, Ngoc TTB, Minh LQ, Nga BTT, Quang DV (2020) Silver nanoparticles as potential antiviral agents against African swine fever virus. Mater Res Express 6(12):1250g9. https://doi.org/10.1088/2053-1591/ab6ad8.

Dzhardimalieva GI, Zharmagambetova AK, Kudaibergenov SE, Uflyand IE (2020) Polymer-Immobilized Clusters and Metal Nanoparticles in Catalysis. Kinet Catal 61(2):198-223. https://doi.org/ $10.1134 / \mathrm{S} 0023158420020044$

Feng Z, Cao S-J (2019) A newly developed electrostatic enhanced pleated air filters towards the improvement of energy and filtration efficiency. Sustain Cities Soc 49:101569

Ferdous Z, Nemmar A (2020) Health impact of silver nanoparticles: a review of the biodistribution and toxicity following various routes of exposure. Int J Mol Sci 21(7):2375

Ge Z-Y, Yang L-M, Xia J-J, Fu X-H, Zhang Y-Z (2020) Possible Aerosol Transmission of COVID-19 and Special Precautions in Dentistry. Journal of Zhejiang University-SCIENCE B 1-8. https:// doi.org/10.1631/jzus.B2010010

Gerba CP, Betancourt WQ (2017) Viral Aggregation: impact on Virus Behavior in the Environment. Environ Sci Technol 51(13):73187325. https://doi.org/10.1021/acs.est.6b05835

Gherasim O, Grumezescu AM, Grumezescu V, Iordache F, Vasile BS, Holban AM (2020) Bioactive Surfaces of Polylactide and Silver Nanoparticles for the Prevention of Microbial Contamination. Materials 13(3):1-15. https://doi.org/10.3390/ma13030768

Ghosal K, Sarkar K (2018) Biomedical Applications of Graphene Nanomaterials and Beyond. ACS Biomater Sci Eng 4(8):26532703. https://doi.org/10.1021/acsbiomaterials.8b00376

Gomathi M, Prakasam A, Rajkumar PV, Rajeshkumar S, Chandrasekaran R, Anbarasan PM (2020) Green Synthesis of Silver Nanoparticles Using Gymnema Sylvestre Leaf Extract and Evaluation of Its Antibacterial Activity. S Afr J Chem Eng 32:1-4. https://doi.org/10.1016/j.sajce.2019.11.005

Gowramma B, Keerthi U, Rafi Mokula, Muralidhara Rao D (2015) Biogenic Silver Nanoparticles Production and Characterization from Native Stain of Corynebacterium Species and Its Antimicrobial Activity. Biotech 5(2):195-201. https://doi.org/10.1007/ s13205-014-0210-4 (3)

Graham K, Ouyang M, Raether T, Grafe T, McDonald B, Knauf P (2002) Polymeric nanofibers in air filtration applications. In: 5th Annual Technical Conference \& Expo of the American Filtration \& Separations Society, Galveston, Texas, pp 9-12

Guimarães ML, Gomes FA, da Silva M, da Costa M, de Oliveira HP (2020) Green Synthesis of Silver Nanoparticles Using Ziziphus Joazeiro Leaf Extract for Production of Antibacterial Agents. Applied Nanoscience (switzerland) 10(4):1073-1081. https://doi. org/10.1007/s13204-019-01181-4

Haimov E, Weitman H, Polani S, Schori H, Zitoun D, Shefi O (2018) Meso-Tetrahydroxyphenylchlorin-Conjugated Gold Nanoparticles as a Tool to Improve Photodynamic Therapy. ACS Appl Mater Interfaces 10(3):2319-2327. https://doi.org/10.1021/ acsami.7b16455

Hirschmann MT, Hart A, Henckel J, Sadoghi P, Seil R, Mouton C (2020) COVID-19 Coronavirus: Recommended Personal Protective Equipment for the Orthopaedic and Trauma Surgeon. Knee Surg Sports Traumatol Arthrosc 0123456789:1-9. https://doi. org/10.1007/s00167-020-06022-4

Hongo-Hirasaki T, Yamaguchi K, Yanagida K, Hayashida H, Ide S (2011) Effects of Varying Virus-Spiking Conditions on a VirusRemoval Filter Planova ${ }^{\mathrm{TM}} 20 \mathrm{~N}$ in a Virus Validation Study of
Antibody Solutions. Biotechnol Prog 27(1):162-169. https://doi. org/10.1002/btpr.533

Huang C, Wang Y, Li X, Ren L, Zhao J, Yi Hu, Zhang Li et al (2020) Clinical Features of Patients Infected with 2019 Novel Coronavirus in Wuhan, China. The Lancet 395(10223):497-506. https:// doi.org/10.1016/S0140-6736(20)30183-5

Huo C, Xiao J, Xiao K, Zou S, Wang M, Qi P, Liu T, Yanxin Hu (2020) Pre-Treatment with Zirconia Nanoparticles Reduces Inflammation Induced by the Pathogenic H5N1 Influenza Virus. Int $\mathrm{J}$ Nanomed 15:661-674. https://doi.org/10.2147/IJN.S221667

Iannazzo D, Pistone A, Ferro S, De Luca L, Monforte AM, Romeo R, Buemi MR, Pannecouque C (2018) Graphene Quantum Dots Based Systems As HIV Inhibitors. Bioconjug Chem 29(9):30843093. https://doi.org/10.1021/acs.bioconjchem.8b00448

Iravani S (2011) Green Synthesis of Metal Nanoparticles Using Plants. Green Chem 13(10):2638-2650. https://doi.org/10.1039/c1gc1 $5386 \mathrm{~b}$

Iravani S, Varma RS (2020) Sustainable Synthesis of Cobalt and Cobalt Oxide Nanoparticles and Their Catalytic and Biomedical Applications. Green Chem. https://doi.org/10.1039/d0gc00885k

Ishihara M, Nguyen VQ, Mori Y, Nakamura S, Hattori H (2015) Adsorption of Silver Nanoparticles onto Different Surface Structures of Chitin/Chitosan and Correlations with Antimicrobial Activities. Int J Mol Sci 16(6):13973-13988. https://doi.org/10. 3390/ijms160613973

Jackson NB, Bakhshayeshi M, Zydney AL, Mehta A, van Reis R, Kuriyel R (2014) Internal Virus Polarization Model for Virus Retention by the Ultipor ${ }^{\circledR}$ VF Grade DV20 Membrane. Biotechnol Prog 30(4):856-863. https://doi.org/10.1002/btpr.1897

Jaggessar A and Prasad K.D.V. Yarlagadda (2020) Modelling the Growth of Hydrothermally Synthesised Bactericidal Nanostructures, as a Function of Processing Conditions. Mat Sci Eng C 108(November 2019): 110434. https://doi.org/10.1016/j.msec. 2019.110434

Jeong, Sang Bin, Ki Joon Heo, and Byung Uk Lee. 2020. “Antimicrobial Air Filters Using Natural Sea Salt Particles for Deactivating Airborne Bacterial Particles.” International Journal of Environmental Research and Public Health 17 (1). https://doi.org/10. 3390/ijerph17010190

Jyothi KR, Beloor J, Jo A, Nguyen MN, Choi TG, Kim JH, Akter S et al (2015) Liver-Targeted Cyclosporine A-Encapsulated Poly (Lactic-Co-Glycolic) Acid Nanoparticles Inhibit Hepatitis C Virus Replication. Int J Nanomed 10:903-921. https://doi.org/ 10.2147/IJN.S74723

Kim J, Yeom M, Lee T, Kim HO, Na W, Kang A, Lim JW et al (2020) Porous Gold Nanoparticles for Attenuating Infectivity of Influenza A Virus. Journal of Nanobiotechnology 18(1):1-11. https:// doi.org/10.1186/s12951-020-00611-8

Konda A, Prakash A, Moss GA, Schmoldt M, Grant GD, Guha S (2020) Aerosol Filtration Efficiency of Common Fabrics Used in Respiratory Cloth Masks. ACS Nano. https://doi.org/10.1021/ acsnano.0c03252

Kora AJ, Sashidhar RB (2018) Biogenic Silver Nanoparticles Synthesized with Rhamnogalacturonan Gum: Antibacterial Activity, Cytotoxicity and Its Mode of Action. Arab J Chem 11(3):313323. https://doi.org/10.1016/j.arabjc.2014.10.036

Kosiol P, Hansmann B, Ulbricht M, Thom V (2017) Determination of Pore Size Distributions of Virus Filtration Membranes Using Gold Nanoparticles and Their Correlation with Virus Retention. J Membr Sci 533(March):289-301. https://doi.org/10.1016/j. memsci.2017.03.043

Kosiol, Peter, Catharina Kahrs, Volkmar Thom, Mathias Ulbricht, and Björn Hansmann. 2019. "Investigation of Virus Retention by Size Exclusion Membranes under Different Flow Regimes." Biotechnology Progress 35 (2). https://doi.org/10.1002/btpr.2747 
Kulathunga KMSDB, Yan CF, Bandara J (2020) Photocatalytic Removal of Airborne Indoor Pollutants by IR Illuminated Silver Coated TiO2 Catalyst: Advantage of One-Dimensional TiO2 Nanostructures in IR Active Photocatalysis. Colloids Surf, A 590(January):124509. https://doi.org/10.1016/j.colsu rfa.2020.124509

Kumar, Hemant, Daima Navya, P N Shivendu, Ranjan Nandita, and Dasgupta Eric. 2020. Nanoscience in Medicine Vol. 1. Anticancer Research. Vol. 40. Springer Nature Switzerland AG

Kumar R, Nayak M, Sahoo GC, Pandey K, Sarkar MC, Yousuf Ansari VNR, Das, et al (2019) Iron Oxide Nanoparticles Based Antiviral Activity of H1N1 Influenza A Virus. J Infect Chemother 25(5):325-329. https://doi.org/10.1016/j.jiac.2018.12. 006

Kuppusamy P, Ichwan SJA, Parine NR, Yusoff MM, Maniam GP, Govindan N (2015) Intracellular Biosynthesis of Au and Ag Nanoparticles Using Ethanolic Extract of Brassica Oleracea L. and Studies on Their Physicochemical and Biological Properties. J Environ Sci (china) 29:151-157. https://doi.org/10.1016/j.jes. 2014.06.050

LaBauve AE, Rinker TE, Noureddine A, Serda RE, Howe JY, Sherman MB, Amy Rasley C, Brinker J, Sasaki DY, Negrete OA (2018) Lipid-Coated Mesoporous Silica Nanoparticles for the Delivery of the ML336 Antiviral to Inhibit Encephalitic Alphavirus Infection. Sci Rep 8(1):1-13. https://doi.org/10.1038/ s41598-018-32033-w

Lancelot A, Clavería-Gimeno R, Velázquez-Campoy A, Abian O, Serrano JL, Sierra T (2017) Nanostructures Based on AmmoniumTerminated Amphiphilic Janus Dendrimers as Camptothecin Carriers with Antiviral Activity. Eur Polymer J 90:136-149. https://doi.org/10.1016/j.eurpolymj.2017.03.012

Lee JH, Wu CY, Lee CN, Anwar D, Wysocki KM, Lundgren DA, Farrah S, Wander J, Heimbuch BK (2009) Assessment of IodineTreated Filter Media for Removal and Inactivation of MS2 Bacteriophage Aerosols. J Appl Microbiol 107(6):1912-1923. https:// doi.org/10.1111/j.1365-2672.2009.04375.x

Lee KJ, Angulo A, Ghazal P, Janda KD (1999) Soluble-Polymer Supported Synthesis of a Prostanoid Library: Identification of Antiviral Activity. Org Lett 1(11):1859-1862. https://doi.org/10. 1021/o1991130j

Lee MY, Yang JA, Jung HS, Beack S, Choi JE, Hur W, Koo H, Kim K, Yoon SK, Hahn SK (2012) Hyaluronic Acid-Gold Nanoparticle/Interferon $\alpha$ Complex for Targeted Treatment of Hepatitis C Virus Infection. ACS Nano 6(11):9522-9531. https://doi.org/ 10.1021/nn302538y

Leisi R, Bieri J, Roth NJ, Ros C (2020) Determination of Parvovirus Retention Profiles in Virus Filter Membranes Using Laser Scanning Microscopy. J Membr Sci 603:118012. https://doi.org/10. 1016/j.memsci.2020.118012

Leung WWF, Chau YT (2019) Experiments on Filtering Nano-Aerosols from Vehicular and Atmospheric Pollutants under Dominant Diffusion Using Nanofiber Filter. Sep Purif Technol 213:186198. https://doi.org/10.1016/j.seppur.2018.12.021

Leung WW, Fong CH, Hung, and Ping Tang Yuen. (2009) Experimental Investigation on Continuous Filtration of Sub-Micron Aerosol by Filter Composed of Dual-Layers Including a Nanofiber Layer. Aerosol Sci Technol 43(12):1174-1183. https://doi.org/10.1080/ 02786820903261086

Leung WWF, Hung CH, Ping TY (2010) Effect of Face Velocity, Nanofiber Packing Density and Thickness on Filtration Performance of Filters with Nanofibers Coated on a Substrate. Sep Purif Technol 71(1):30-37. https://doi.org/10.1016/j.seppur. 2009.10.017

Liu H, Cao C, Huang J, Chen Z, Chen G, Lai Y (2020) Progress on Particulate Matter Filtration Technology: Basic Concepts, Advanced
Materials, and Performances. Nanoscale 12(2):437-453. https:// doi.org/10.1039/c9nr08851b

Malik MA, Wani MY, Hashim MA (2012) Microemulsion Method: A Novel Route to Synthesize Organic and Inorganic Nanomaterials. 1st Nano Update. Arab J Chem 5(4):397-417. https://doi.org/10. 1016/j.arabjc.2010.09.027

Matava CT, Yu J and Denning S (2020) Clear plastic drapes may be effective at limiting aerosolization and droplet spray during extubation: implications for COVID-19. Can J Anesth, 1-3. https:// doi.org/10.1007/s12630-020-01649-w

Mazurkova NA, Spitsyna YuE, Shikina NV, Ismagilov ZR, Zagrebel'nyi SN, Ryabchikova EI (2010) Interaction of Titanium Dioxide Nanoparticles with Influenza Virus. Nanotechnol Russ 5(5-6):417-420. https://doi.org/10.1134/S1995078010050174

Mazurkow JM, Yüzbasi NS, Domagala KW, Pfeiffer S, Kata D, Graule T (2020) Nano-Sized Copper (Oxide) on Alumina Granules for Water Filtration: Effect of Copper Oxidation State on Virus Removal Performance. Environ Sci Technol 54(2):1214-1222. https://doi.org/10.1021/acs.est.9b05211

Milovanovic M, Arsenijevic A, Milovanovic J, Kanjevac T and Arsenijevic N (2017) "Nanoparticles in Antiviral Therapy." Antimicrobial Nanoarchitectonics: From Synthesis to Applications, 383-410.https://doi.org/10.1016/B978-0-323-52733-0.00014-8

Mohamed HE, Ahmed SA, Khalil AT, Ali M, Zohra T, Akhtar R, Ikram A, Shinwari ZK, Maaza M (2020) Promising Antiviral, Antimicrobial and Therapeutic Properties of Green Nanoceria. Nanomedicine 15(5):467-488. https://doi.org/10.2217/ nnm-2019-0368

Moradi MT, Karimi A, Rafieian-Kopaei M, Fotouhi F (2017) In Vitro Antiviral Effects of Peganum Harmala Seed Extract and Its Total Alkaloids against Influenza Virus. Microb Pathog 110:42-49. https://doi.org/10.1016/j.micpath.2017.06.014

Nabila N, Suada NK, Denis D, Yohan B, Adi AC, Veterini AS, Anindya AL, Tedjo Sasmono R, Rachmawati H (2019) Antiviral Action of Curcumin Encapsulated in Nanoemulsion against Four Serotypes of Dengue Virus. Pharm Nanotechnol 8(1):54-62. https://doi.org/ 10.2174/2211738507666191210163408

Nakamura S, Sato M, Sato Y, Ando N, Takayama T, Fujita M, Ishihara M (2019) Synthesis and application of silver nanoparticles (Ag NPs) for the prevention of infection in healthcare workers. Int $\mathrm{J}$ Mol Sci 20(15):3620

Ortega-Berlanga B, Hernández-Adame L, del Angel-Olarte C, Aguilar F, Rosales-Mendoza S, Palestino G (2020) Optical and Biological Evaluation of Upconverting Gd2O3:Tb3+/Er3+ Particles as Microcarriers of a Zika Virus Antigenic Peptide. Chem Eng J 385(November):123414. https://doi.org/10.1016/j.cej.2019. 123414

Owens GJ, Singh RK, Foroutan F, Alqaysi M, Han CM, Mahapatra C, Kim HW, Knowles JC (2016) Sol-Gel Based Materials for Biomedical Applications. Prog Mater Sci 77:1-79. https://doi. org/10.1016/j.pmatsci.2015.12.001

Pan H, Zhang P, Gao D, Zhang Y, Li P, Liu L, Wang Ce, Wang H, Ma Y, Cai L (2014) Noninvasive Visualization of Respiratory Viral Infection Using Bioorthogonal Conjugated Near-InfraredEmitting Quantum Dots. ACS Nano 8(6):5468-5477. https://doi. org/10.1021/nn501028b

Park DH, Joe YH, Hwang J (2019) Dry Aerosol Coating of Anti-Viral Particles on Commercial Air Filters Using a High-Volume Flow Atomizer. Aerosol and Air Quality Research 19(7):1636-1644. https://doi.org/10.4209/aaqr.2019.04.0212

Park DH, Joe YH, Piri A, An S, Hwang J (2020) Determination of Air Filter Anti-Viral Efficiency against an Airborne Infectious Virus. J Hazard Mater 396(March):122640. https://doi.org/10.1016/j. jhazmat.2020.122640

Park HH, Park S, Ko G, Woo K (2013) Magnetic Hybrid Colloids Decorated with Ag Nanoparticles Bite Away Bacteria and Chemisorb 
Viruses. J Mater Chem B 1(21):2701-2709. https://doi.org/10. $1039 / \mathrm{c} 3 \mathrm{tb} 20311 \mathrm{e}$

Park KT, Hwang J (2014) Filtration and Inactivation of Aerosolized Bacteriophage MS2 by a CNT Air Filter Fabricated Using Electro-Aerodynamic Deposition. Carbon 75:401-410. https://doi. org/10.1016/j.carbon.2014.04.019

Patil HB, Borse SV, Patil DR, Patil UK, Patil HM (2011) Synthesis of Silver Nanoparticles by Microbial Method and Their Characterization. Archives of Physics Research 2(3):153-158

Pierre AC (2020) Introduction to Sol-Gel Processing. Second. Springer Nature Switzerland

Pollock S, Nichita NB, Böhmer A, Radulescu C, Dwek RA, Zitzmann N (2010) Polyunsaturated Liposomes Are Antiviral against Hepatitis B and C Viruses and HIV by Decreasing Cholesterol Levels in Infected Cells. Proc Natl Acad Sci USA 107(40):1717617181. https://doi.org/10.1073/pnas.1009445107

Rane AV, KannyAbitha KVK, Thomas S (2018) Methods for Synthesis of Nanoparticles and Fabrication of Nanocomposites. Elsevier Ltd., Synthesis of Inorganic Nanomaterials. https://doi.org/10. 1016/b978-0-08-101975-7.00005-1

Rathore Gulshan, Gupta Aparna, Singh Lalit (2020) An Eco-Friendly Approach for Fabrication of Silver Nanoparticles by Using Ascorbic Acid from Various Native Sources. International Journal of Pharmaceutical Research 12(2):41-48. https://doi.org/10. 31838/ijpr/2020.12.02.0002

Rengasamy S, Fisher E, Shaffer RE (2010) Evaluation of the Survivability of MS2 Viral Aerosols Deposited on Filtering Face Piece Respirator Samples Incorporating Antimicrobial Technologies. Am J Infect Control 38(1):9-17. https://doi.org/10.1016/j.ajic. 2009.08.006

Ringe RP, Cruz VM, Portillo PD, Ketas TJ, Ozorowski G, Nogal B, Perez L et al (2019) Neutralizing Antibody Induction by HIV-1 Envelope Glycoprotein SOSIP Trimers on Iron Oxide Nanoparticles May Be Impaired by Mannose Binding Lectin. J Virol 94(6):1-32. https://doi.org/10.1128/jvi.01883-19

Röhrig, Céline, and Stefan Diebels. 2019. "Experimental Studies." Mathematical Engineering 13 (November 1995): 143-75. https:// doi.org/10.1007/978-3-662-57957-2_6

Rosi NL, Mirkin CA (2005) Nanostructures in Biodiagnostics. Chem Rev 105(4):1547-1562. https://doi.org/10.1021/cr030067f

Rzaev ZM, Sadykh-Zade SI (1973) Radical Copolymerization of Maleic Anhydride With Organotin Acrylates. J Polym Sci, Part c, Polym Symp 552(42):541-552. https://doi.org/10.1002/polc. 5070420205

Salem SS, Fouda A (2020) Green Synthesis of Metallic Nanoparticles and Their Prospective Biotechnological Applications: An Overview. Biol Trace Elem Res. https://doi.org/10.1007/ s12011-020-02138-3

Sambaer W, Zatloukal M, Kimmer D (2012) 3D Air Filtration Modeling for Nanofiber Based Filters in the Ultrafine Particle Size Range. Chem Eng Sci 82:299-311. https://doi.org/10.1016/j.ces. 2012.07.031

Sametband M, Kalt I, Gedanken A, Sarid R (2014) Herpes Simplex Virus Type-1 Attachment Inhibition by Functionalized Graphene Oxide. ACS Appl Mater Interfaces 6(2):1228-1235. https://doi. org/10.1021/am405040z

Sánchez-López E, Gomes D, Esteruelas G, Bonilla L, Lopez-Machado AL, Galindo R, Cano A et al (2020) Metal-Based Nanoparticles as Antimicrobial Agents: An Overview. Nanomaterials 10(2):143. https://doi.org/10.3390/nano10020292

Schutz JA, Church JS (2011) Respiratory Protection for Physiologically Straining Environments. Text Res J 81(13):1367-1380. https:// doi.org/10.1177/0040517511402127

Senapathi Jagadeesh, Bommakanti Akhila, Mallepalli Suresh, Mukhopadhyay Satyajit, Kondapi Anand K (2020) Sulfonate Modified Lactoferrin Nanoparticles as Drug Carriers with Dual
Activity against HIV-1. Colloids and Surfaces B: Biointerfaces 191(November 2019):110979. https://doi.org/10.1016/j.colsurfb. 2020.110979

Sepúlveda-Crespo D, Sánchez-Rodríguez J, Serramía MJ, Gómez R, Mata FJDL, Jiménez JL, Muñoz-Fernández MÁ (2015) Triple Combination of Carbosilane Dendrimers, Tenofovir and Maraviroc as Potential Microbicide to Prevent HIV-1 Sexual Transmission. Nanomedicine 10(6):899-914. https://doi.org/10.2217/ nnm.14.79

Shah M, Fawcett D, Sharma S, Tripathy SK, Poinern GEJ (2016) Green synthesis of metallic nanoparticles via biological entities. Materials 8(11):7278-7308

Siadati SA, Afzali M, Sayyadi S (2020) Could silver nano-particles control the 2019-nCoV virus?; An urgent glance to the past. Chemical Review and Letters 3(1):9-11. https://doi.org/10. 22034/CRL.2020.224649.1044.

Siegel JD, Rhinehart E, Jackson M, Chiarello L (2007) 2007 guideline for isolation precautions: preventing transmission of infectious agents in health care settings. Am J Infec Control 35(10):S65-S164

Slepička P, Kasálková NS, Siegel J, Kolská Z, Švorčík V (2020) Methods of Gold and Silver Nanoparticles Preparation. Materials 13(1):1. https://doi.org/10.3390/ma13010001

Slocum A, Burnham M, Genest P, Venkiteshwaran A, Chen D, Hughes J (2013) Impact of Virus Preparation Quality on Parvovirus Filter Performance. Biotechnol Bioeng 110(1):229-239. https://doi. org/10.1002/bit.24600

Silva SE, De JM, Hanchuk TDM, Santos MI, Kobarg J, Bajgelman MC, Cardoso MB (2016) Viral Inhibition Mechanism Mediated by Surface-Modified Silica Nanoparticles. ACS Appl Mater Interfaces 8(26):16564-16572. https://doi.org/10.1021/acsami. $6 \mathrm{~b} 03342$

Stetzenbach LD, Buttner MP, Cruz P (2004) Detection and Enumeration of Airborne Biocontaminants. Curr Opin Biotechnol 15(3):170-174. https://doi.org/10.1016/j.copbio.2004.04.009

Sun Q, Leung WWF (2019) Charged PVDF Multi-Layer Filters with Enhanced Filtration Performance for Filtering Nano-Aerosols. Sep Purif Technol 212:854-876. https://doi.org/10.1016/j.seppur.2018.11.063

Sun Q, Leung WWF (2020) Enhanced Nano-Aerosol Loading Performance of Multilayer PVDF Nanofiber Electret Filters. Sep Purif Technol 240:116606. https://doi.org/10.1016/j.seppur.2020. 116606

Szymańska E, Orłowski P, Winnicka K, Tomaszewska E, Bąska P, Celichowski G, Jarosław Grobelny J, Basa A, Krzyżowska M (2018) Multifunctional tannic acid/silver nanoparticle-based mucoadhesive hydrogel for improved local treatment of HSV infection: invitro and in vivo studies. Int J Mol Sci 19(2):387. https://doi.org/10.3390/ijms19020387

Tavakoli A, Hashemzadeh MS (2020) Inhibition of Herpes Simplex Virus Type 1 by Copper Oxide Nanoparticles. J Virol Methods 275:113688. https://doi.org/10.1016/j.jviromet.2019.113688

Tellier R (2006) Review of Aerosol Transmission of Influenza A Virus. Emerg Infect Dis 12(11):1657-1662. https://doi.org/10.3201/ eid1211.060426

Thakur R, Das D, Das A (2013) Electret Air Filters. Sep Purif Rev 42(2):87-129. https://doi.org/10.1080/15422119.2012.681094

Thamboo A, Lea J, Sommer DD, Sowerby L, Abdalkhani A, Diamond C, Ham J, et al (2020) Clinical evidence based review and recommendations of aerosol generating medical procedures in otolaryngology-head and neck surgery during the COVID-19 pandemic. J Otolaryngol Head Neck Surg 49:1-14

Tian E, Mo J, Li X (2018) Electrostatically Assisted Metal Foam Coarse Filter with Small Pressure Drop for Efficient Removal of Fine Particles: Effect of Filter Medium. Build Environ 144:419 426. https://doi.org/10.1016/j.buildenv.2018.08.026 
UCSF (2020) "Reduce Your Risk of Serious Lung Disease Caused by Corona Virus by Quitting Smoking and Vaping," 2020. https:// tobacco.ucsf.edu/reduce-your-risk-serious-lung-disease-causedcorona-virus-quitting-smoking-and-vaping. Accessed 30 Aug 2020

Vonnemann J, Sieben C, Wolff C, Ludwig K, Böttcher C, Herrmann A, Haag R (2014) Virus Inhibition Induced by Polyvalent Nanoparticles of Different Sizes. Nanoscale 6(4):2353-2360. https:// doi.org/10.1039/c3nr04449a

Wang LY, Yu LE, Chung TS (2020) Effects of Relative Humidity, Particle Hygroscopicity, and Filter Hydrophilicity on Filtration Performance of Hollow Fiber Air Filters. J Membr Sci 595(August):117561. https://doi.org/10.1016/j.memsci.2019. 117561

Wang X, Deng Y, Shi H, Mei Z, Zhao H, Xiong W, Peng Liu Yu, Zhao CQ, Tang R (2010) Functional Single-Virus-Polyelectrolyte Hybrids Make Large-Scale Applications of Viral Nanoparticles More Efficient. Small 6(3):351-354. https://doi.org/10.1002/ smll.200901795

Wang Y, Canady TD, Zhou Z, Tang Y, Price DN, Bear DG, Chi EY, Schanze KS, Whitten DG (2011) Cationic Phenylene Ethynylene Polymers and Oligomers Exhibit Efficient Antiviral Activity. ACS Appl Mater Interfaces 3(7):2209-2214. https://doi.org/10. 1021/am200575y

Wang Z, Liu H, Yang SH, Wang T, Liu C, Charles Cao Y (2012) Nanoparticle-Based Artificial RNA Silencing Machinery for Antiviral Therapy. Proc Natl Acad Sci USA 109(31):12387-12392. https:// doi.org/10.1073/pnas.1207766109

WHO (2019) Interim Guidance Health Worker Exposure Risk Assessment and Management in the Context of COVID-19 Virus. March. Society 2(1):1-6. https://doi.org/10.1017/CBO9781107 415324.004

Leung WW-F, Sun Q (2020) Charged PVDF multilayer nanofiber filter in filtering simulated airborne novel coronavirus (COVID-19) using ambient nano-aerosols. Sep Purif Technol 245:116887

Yamaguchi K, Miyagawa E, Takahashi H, Miyazaki T, Ikeda H (2007) Electron Microscopic Estimation of Removal of Parvovirus B19 (HPVB19) by Nanofiltration with a Novel Filter Membrane. J Membr Sci 298(1-2):99-109. https://doi.org/10.1016/j.memsci. 2007.04.009

Yang XX, Li CM, Li YF, Wang J, Huang CZ (2017) Synergistic Antiviral Effect of Curcumin Functionalized Graphene Oxide against
Respiratory Syncytial Virus Infection. Nanoscale 9(41):1608616092. https://doi.org/10.1039/c7nr06520e

Ye Na, Chen H, Wold EA, Shi PY, Zhou J (2016) Therapeutic Potential of Spirooxindoles as Antiviral Agents. ACS Infectious Diseases 2(6):382-392. https://doi.org/10.1021/acsinfecdis.6b00041

Yoon KY, Byeon JH, Park JH, Hwang J (2007) Susceptibility Constants of Escherichia Coli and Bacillus Subtilis to Silver and Copper Nanoparticles. Sci Total Environ 373(2-3):572-575. https://doi. org/10.1016/j.scitotenv.2006.11.007

Yousaf M, Huang H, Li P, Wang C, Yang Y (2017) Fluorine Functionalized Graphene Quantum Dots as Inhibitor against HIAPP Amyloid Aggregation. ACS Chem Neurosci 8(6):1368-1377. https://doi.org/10.1021/acschemneuro.7b00015

Zeedan GSG, EL-Razik KKA, Allam AM, Abdalhamed AM, Zeina HAA (2020) Evaluations of potential antiviral effects of green zinc oxide and silver nanoparticles against bovine herpesvirus-1. Adv Anim Vet Sci 8(4):433-443

Zeroual S, Estellé P, Cabaleiro D, Vigolo B, Emo M, Halim W, Ouaskit S (2020) Ethylene Glycol Based Silver Nanoparticles Synthesized by Polyol Process: Characterization and Thermophysical Profile. J Mol Liq 310:113229. https://doi.org/10.1016/j.molliq. 2020.113229

Zhang HZ, Zhang C, Zeng GM, Gong JL, Xiao Ming Ou, Huan SY (2016) Easily Separated Silver Nanoparticle-Decorated Magnetic Graphene Oxide: Synthesis and High Antibacterial Activity. J Colloid Interface Sci 471:94-102. https://doi.org/10.1016/j.jcis. 2016.03.015

Zhang X, Zhao P, Kunxin Wu, Zhang Y, Peng M, Liu Z (2014) Compositional Equivalency of RNAi-Mediated Virus-Resistant Transgenic Soybean and Its Nontransgenic Counterpart. J Agric Food Chem 62(19):4475-4479. https://doi.org/10.1021/jf500859c

Zhu Na, Zhang D, Wang W, Li X, Yang Bo, Song J, Zhao X et al (2020) A Novel Coronavirus from Patients with Pneumonia in China, 2019. N Engl J Med 382(8):727-733. https://doi.org/10.1056/ NEJMoa2001017

Publisher's note Springer Nature remains neutral with regard to jurisdictional claims in published maps and institutional affiliations. 